\title{
Desmistificando o Oriente Médio
}

Sebastião André Alves de Lima Filho

Lançado no instante em que a "Primavera Árabe" rompia com o longo inverno político que congelara a democracia no Oriente Médio, o livro de Fábio Bacila contribui para o entendimento dos motivos que fizeram os povos oprimidos da região retardar, por décadas, a construção de Estados nacionais com instituições sólidas e democráticas, bem como nos indica o modo como ocorreu a formação dos estigmas que pairam sobre os movimentos de resistência das sociedades árabes.

Em essência, "Oriente Médio desmistificado" parece nortear-se pelas mesmas inquietações que compeliram Barrington Moore (1987) a compreender os fundamentos sociais da obediência e da revolta. Apesar de escolher como recorte empírico os movimentos operários alemães e russos, a questão que inicia e circula toda
REFERÊNCIA: BACILA SAHD, F. Oriente Médio desmistificado: fundamentalismo, terrorismo e barbárie. Curitiba: Editora CRV, 2011.

a obra de Moore encontra ecos na de Fábio em relação aos povos árabes: Por que as pessoas "aceitam a condição de vítimas de suas sociedades" enquanto, em outras ocasiões, "elas se tornam tão iradas e buscam, com energia e paixão", fazer alguma coisa para mudar suas condições? (MOORE, 1987, p. 8).

O olhar de Fábio Bacila mira na desmistificação de discursos e interpretações no tocante ao Oriente Médio tecidos pelo Ocidente, carregados de desinformação e criando mitos no intuito de ocultar as origens e os motivos de instabilidade política e humanitária crescente na região. Este longo processo de mascaramento desenhado pelas potências ocidentais acerca das suas disputas com os povos árabes, principalmente os palestinos, aponta Bacila, foi levado a efeito tanto pela produção bibliográfica

Sebastião André Alves de Lima Filho:

Professor da Universidade Federal do Ceará e pesquisador do Observatório das Nacionalidades. 
de intelectuais que acreditam na predestinação da superioridade ocidental sobre o Oriente quanto pela cobertura midiática que acompanha, sem imparcialidade e com preconceito, o enredo de vidas humanas despedaçadas.

Bernard Lewis (2002) é referido como um dos intelectuais que reproduzem, através dos seus livros, a visão segundo a qual o Oriente Médio "deu errado" devido às peculiaridades culturais e religiosas dos árabes, que retardaram ou impediram a modernização "oferecida" pelos ocidentais. Em nenhum momento menciona que as sociedades médio-orientais foram dominadas e expropriadas, por gerações, dos seus meios de vida material e espiritual. Até mesmo as estratégias de resistência utilizadas pelos muçulmanos se deveram à superioridade do pensamento ocidental. Como preconiza Lewis (2002, p. 73).

Alguns dos movimentos de revolta contra o domínio ocidental foram inspirados pela religião e lutaram em nome do islã. Mas os mais eficazes nessa época os que realmente conquistaram independência política - foram liderados por intelectuais ocidentalizados que combateram o Ocidente com suas próprias armas intelectuais.

Conforme lembra Fábio Bacila (2011), citando Edward Said (1990), o discurso orientalista procura desconstruir e anular as especifici- dades culturais, políticas e econômicas que tornam as sociedades orientais possíveis, qualificandoas de inferiores e reticentes ao progresso.

"Oriente Médio desmistificado" se apoia nas ideias de Edward Said quando aponta os mecanismos de construção mistificada do "fundamentalista", do "bárbaro" e do "terrorista"; indivíduos irracionais levados, pela religião, a destilar um ódio cego a tudo que é ocidental. No entanto, o orientalismo jamais assinala a causa da "cegueira" desses indivíduos, que é a expropriação da sua casa, da sua terra, da sua água, do seu rebanho, da sua gente.

Se a mistificação do Oriente Médio começou a se produzir no século XIX, primeiro nas universidades europeias e depois através da literatura, nos séculos posteriores os meios de comunicação de massa se encarregaram de difundir, em escala global, a imagem estereotipada do árabe e dos seus martírios. As coberturas midiáticas só evidenciam, em relação ao Oriente Médio, os acontecimentos que favorecem, de alguma forma, as posições do Estado judeu e das nações ocidentais. Neste sentido, é esclarecedor o discurso proferido pelo primeiro-ministro de Israel, Benjamin Netanyahu, no Congresso americano em 24 de maio de 2011.

Enquanto Netanyahu discursava, alguns milhares de palestinos 
estavam confinados em campos de refugiados, e outros tantos sendo humilhados em postos de passagem, controlados por soldados judeus em terras palestinas. Como sempre, a mídia não focalizou suas câmaras para o drama destes, mas sim para a importância das palavras ditas por aquele aos congressistas norte-americanos.

Segundo "Oriente Médio desmistificado", o discurso de Netanyahu seria o modelo perfeito de como se constrói uma imagem enviesada acerca dos problemas do Oriente Médio com base na ótica ocidental. De fato, os efeitos do seu discurso propiciam um rico material de como se processa a mistificação sobre os países médios orientais. Com ampla cobertura da mídia internacional, a fala do primeiro-ministro era ininterruptamente calada, pelos congressistas, os quais, de pé, aplaudiam o orador quando este lembrava a importância de Israel para o Ocidente, e quando indicava aos civilizados o atraso dos povos árabes.

Israel não tem melhor amigo do que a América. E a América não tem um amigo melhor do que Israel. Estamos unidos na defesa da democracia. Unidos na promoção da paz. Para combater o terrorismo. Felicitações, América. Congratulações, senhor presidente. Vocês pegaram Bin Laden. Por fim! Israel sempre adotou esse caminho, mas no Oriente Médio ele sempre foi rejeitado. Numa região onde as mulheres são apedrejadas, os homossexuais são enforcados, cristãos são perseguidos, Israel se destaca. É diferente. ${ }^{1}$

A importância do livro de Bacila reside, justamente, em revelar as engrenagens que mascaram as dinâmicas dos eternos conflitos no Oriente Médio. O repertório de conceitos como "antissemitismo", "terrorismo", "fundamentalismo" e "radicalismo islâmico", reproduzidos por aqueles que falam em nome do Ocidente e difundidos pela mídia, lembra Fábio Bacila, amplia a desinformação dominante sobre a região mais cobiçada do planeta. Tais conceitos funcionam, na verdade, como liturgias políticas.

Como assevera Rivière (1989, p. 13), "liturgia, cerimônia, festa, rito", são definições que expressam conotações religiosas. Entretanto, não há movimentação política, de partido ou de "regime, que deixe de recorrer à série de atos solenes, repetitivos e codificados, de ordem verbal, gestual e postural, de forte conteúdo simbólico". Algumas encenações políticas públicas são profundamente carregadas de ritualização, principalmente aquelas que buscam "afirmar a integração de uma coletividade, exibem uma

1 Discurso obtido no jornal "Estado de São Paulo". Disponível em: <www.estadao.com. $\mathrm{br} /$ noticias/internacional,leia-a-integrado-discurso-de-netanyahu-no-congressoamericano,723585,0.htm $>$.Acesso em: 10 de outubro de 2011. 
identidade e exprimem uma vontade de existir na comunhão de certos ideais".

Estas argumentações são utilizadas pelos ocidentais, recorrentemente, quando tentam inferiorizar ou estigmatizar os povos árabes, mesmo nos momentos em que Israel busca justificar o terrorismo do Estado judeu que violenta a vida dos palestinos. Mais uma vez as palavras pronunciadas por Benjamin Netanyahu, no Congresso dos Estados Unidos, corroboram os argumentos contidos no livro "Oriente Médio desmistificado":

Esta é a terra dos nossos ancestrais, a Terra de Israel, para a qual Abraão levou a noção de um só Deus, onde David enfrentou Golias e Isaías teve a visão da paz eterna. Nenhuma distorção da história conseguirá negar os quatro mil anos de vínculo entre o povo judeu e a terra judaica. ${ }^{2}$

Fábio Bacila reconhece a "pesada carga e ampla desinformação sobre o Oriente Médio", expressa, principalmente, no mito de ódio ao Ocidente. Para desmistificar essa falsa percepção, recorre a dois conceitos fundamentais para a compreensão do conjunto da obra: o de "barbárie", definido por Tzvetan

2 Discurso obtido no jornal "Estado de São Paulo". Disponível em: <www.estadao.com. $\mathrm{br} /$ noticias/internacional,leia-a-integra-dodiscurso-de-netanyahu-no-congresso-americano, $723585,0 . h t m>$. Acesso em: 10 de outubro de 2011.
Todorov, e o de mitologia, do intelectual francês Roland Barthes.

Barthes (1985, p.131), ao indagar o que é o mito, oferece a resposta à sua própria pergunta: "mito é uma fala". No entanto, significa um discurso, uma mensagem, ou ainda um sistema de comunicação que denota as falsas evidências que desorientam a natureza e a história. Funcionaria como um sistema de significação do real com limitações históricas e condições de articulação bem definidas.

Ainda de acordo com Roland Barthes (1985), os mitos, no sentido de ideologização, ou seja, de criar uma falsa consciência sobre o real, não ocultam nada, pois têm como finalidade deformar e disseminar um conceito intencional e não fazê-lo desaparecer. Os mitos, como "linguagem roubada", não restituem o significado original da fala/imagem furtada; pelo contrário, distorcem-na segundo o interesse do seu criador. É nessa dialética de "roubo e restituição" que se realiza a "furtiva inflexão do sentido original".

Qual é a função específica do mito? Transformar um sentido em forma. Isto é, o mito é sempre um roubo de linguagem. [...] De fato, nada pode proteger-se do mito; o mito pode desenvolver o seu esquema a partir de qualquer sentido, não importa qual. [...] A língua, que é a linguagem mais freqüentemente 
roubada pelo mito, oferece fraca resistência (BARTHES, 1985, p.152).

Na obra de Fábio Bacila, no tocante ao conceito "Oriente Médio mitificado", o difundido terrorismo árabe-islâmico sobressai como um dos principais mitos. Adquiriu consistência global exatamente por expressar a principal característica do mito definido por Barthes, segundo o autor de "Oriente Médio desmistificado":

Enquanto o que existe entre significante e significado são relações de valor, o consumidor do mito é induzido a considerar a significação como um sistema de fatos: ou seja, o mito é lido como um sistema factual, ao passo que é apenas um sistema semiológico de valores (BACILA SAHD, 2011, p.20).

A consequência mais evidente do mito que envolve o entendimento sobre o Oriente Médio é a identificação das suas sociedades com a barbárie. A barbárie, em seu valor moral absoluto, em contraposição à civilização, pode ser compreendida como a "negação da alteridade e plena humanidade do outro", lembra Fábio Bacila. Apoiando-se nos argumentos de Tzvetan Todorov (2010), arremata:

É a atitude que, julgando-o radicalmente diferente de si, infringindo-o um tratamento ofensivo e considerando-o desumano, monstruoso ou selvagem (terrorista), o exclui das fronteiras da humanidade, tor- nando-o passível de ser caçado, extirpado, submetido, torturado e, finalmente, exterminado para o "bem geral" (BACILA SAHD, 2011, p. 23).

Na contemporaneidade, a construção da imagem do árabemuçulmano como bárbaro começa a se delinear nos anos 1960, quando se intensificam as ações armadas dos palestinos contra $\mathrm{O}$ domínio israelense. No entanto, foi a partir dos acontecimentos do 11 de setembro, demonstra o livro de Fábio Bacila, que o mundo foi massivamente induzido a consumir a ideia do "árabe como bárbaro", aprofundando ainda mais a manipulação de informações sobre os povos do Oriente Médio.

O mérito de "Oriente Médio desmistificado" reside, também, em demonstrar o modo como o Ocidente construiu a imagem distorcida dos reais motivos que fizeram os árabes se revoltarem. Assim, os oito capítulos da obra descrevem as causas concretas que levaram os povos árabes, muçulmanos ou não, a recorrerem à violência para alcançar seus objetivos político-ideológicos, "explicando tais atitudes em termos de violência sofrida, opressão, desespero, falta de outros recursos e tentativa de mudar o status quo político e social" (BACILA SAHD, 2011, p. 21).

No livro, Fábio Bacila discute o cenário geral do Oriente Médio, focalizando os principais aconte- 
cimentos que contribuíram para o aprofundamento da violência na região. A obra evidencia, também, a "complexidade sócio-política presente nas questões identitárias", que atuam nos conflitos do Oriente Médio contemporâneo. Aqui Bacila trata do problema da construção das nações, que foram criadas artificialmente, no Oriente Médio, após a Primeira Guerra Mundial, de acordo com os interesses das potências vitoriosas. Ao fazer um levantamento histórico do desenrolar de acordos e desacordos entre os países ocidentais acerca da divisão do Oriente Médio, Bacila (2011, p. 27) afirma:

Se hoje, uma das principais fontes de seus problemas ainda são os interesses internacionais, cabe lembrar que no contexto do imperialismo europeu, na gênese de sua formação, mesmo antes da Primeira Guerra Mundial, a região era cobiçada pelas grandes potências da época. A questão era como dividi-la adequando-se ao frágil equilíbrio político internacional. Com a deflagração da guerra e a aliança teuto-otomana, parte dessa questão perdia sua complexidade: agora, resumia-se a repartição dos espólios entre os vencedores (Inglaterra, França, Estados Unidos, Rússia e Itália).

Passando pelo colonialismo europeu, as duas guerras mundiais, a criação do Estado de Israel e a Guerra Fria, Bacila analisa como esses acontecimentos redefiniram as relações de forças entre os países que disputavam o domínio sobre a região, afirmando, ainda, que foi durante a cobertura "desses conflitos médioorientais que começa a se constituir o atual léxico ideológico estadunidense e israelense para acusar inimigos e legitimar guerras" (BACILA SAHD, 2011, p. 52). Portanto, é nesse contexto que o léxico ideológico, construído tanto pelas potências ocidentais quanto por Israel, desponta na mídia como armas ideológicas eficientes para mascarar assassinatos, expropriações de fontes de energia e de território e justificando "violações às soberanias estatais".

"Oriente Médio desmistificado", traz, ainda, um apanhado da documentação histórica disponível na internet que descreve as negociações de ingleses, franceses, alemães e norte-americanos na partilha do Oriente Médio, privilegiando a discussão do imperialismo anglo-francês para a construção dos Estados-nação do Oriente Médio moderno. De modo geral, caracteriza a dominação de mercados e a conquista de territórios, levados a efeito pelos países imperialistas em nome de uma pretensa inferioridade dos povos orientais e o consequente dever dos ocidentais de civilizá-los. Bacila (2011, p. 94) conclui, afirmando que:

Se antes o discurso oficial que legitimava os interesses das potências era levar os benefícios 
da civilização às populações nativas médio-orientais, atualmente não há muita diferença. Hoje, os supostos benefícios que fundamentam as intervenções e as conseqüentes catástrofes que continuam a assolar a região são: o extermínio de elementos altamente ameaçadores [os terroristas]; a implementação da democracia [...].

A contribuição dos argumentos de Fábio Bacila reside na desconstrução das imagens produzidas pelo Ocidente para legitimar as guerras no Oriente Médio, motivadas por interesses puramente econômicos. Ao final da obra compreendemos que afirmar que os árabes são, em potencial, "fundamentalistas islâmicos", interessados em islamizar o mundo e aniquilar aqueles que não se curvarem ao Alcorão, é não dar voz a indivíduos que foram dominados e massacrados por gerações, e que não têm nem mesmo o direito de se locomover dentro do seu próprio território.

\section{REFERÊNCIAS}

BARTHES, R. Mitologias. São Paulo:

Difel, 1985.

\section{LEWIS, B. O que deu errado no}

Oriente Médio? Rio de Janeiro:

Zahar, 2002.

MOORE, B. Injustiça - As bases

sociais da obediência e da revolta. São

Paulo: Editora Brasiliense, 1987.

RIVIÈRE. C. As liturgias políticas.

Rio de Janeiro: Imago, 1989. 